\title{
The tandem long-term program 2012-2021 and some results on the rehabilitation of soil biology of intensively farmed agricultural land in Germany
}

\author{
Wolfgang Nowick \\ daRostim Private Institute of Applied Biotechnology, Waldheim, Germany, E-mail: info@darostim.de
}

\section{Introduction}

In recent decades, intensively used agricultural land in Germany has lost much of its natural soil fertility due to the use of extremely high levels of mineral nitrogen fertilizer and the intensive use of pesticides. Since 2005, we have been attempting to improve the biological soil fertility of these intensively used areas on about 170 agricultural areas with different soil indexes. The international longterm program Tandem ${ }^{12 / 21}$ (2012-2021) and the two previous research projects Radostim A*B (20052008) and future ${ }^{9 / 12}$ (2009-2012) have been investigating the potential of phytohormone-humic acid combinations (PHC) to increase soil biological fertility and to create a biological nutrient reserve in the soil.

In the spring, PHCs are applied during the growing season. They stimulate the photosynthesis of the plants and promote the development of soil biology. Since 2012, e.g. with the start of the tandem program, the same areas has also been undertaking an additional PHC application in the autumn in order to activate the conversion of the organic material to humus and to stabilize soil biology in the winter phase. In the following, the used PHC preparations and current results of the monitoring biological soil parameters for the period 2006 to 2018 as well as results for the increase of yields with simultaneous reduced nitrogen use are presented.

\section{The PHC-preparation system (array) daRostim ${ }^{\circledR}$ TANDEM}

The array daRostim ${ }^{\circledR}$ TANDEM has been used. It is free of chemically synthesized active ingredients and consists of 6 modifications, 3 for spring application (leaf application - F30, F50, F70) and 3 for autumn application (soil application - H30, H50, H70). By the modular selection of the composition of humic acids with a mass fraction of 50 to $85 \%$ of the organic substance and other plantphysiologically active components (natural plant hormone analogues, fatty acids, amino acids, polysaccharides) with a mass fraction of 0.01 to $0.07 \%$ of the organic substance, the modifications are optimally adapted to specific soil index (AZ). All 6 TANDEM modifications contain water with a mass fraction of about $90 \%$ as well as macro and micro elements. daRostim ${ }^{\circledR}$ TANDEM can be used in all field crops. The application is done with the sprayer, in the spring solo or together with the first phytosanitary measure, in the fall after harvest and before the winter sowing or intercrop essential parts of the ground $(<30-40 \%)$ covered. The uniform dosage is 0.4 liters/ha [1].

Table 1. The daRostim TANDEM Array

\begin{tabular}{|l|c|c|c|}
\hline & Soil Index: $20-40$ & Soil Index: $20-40$ & Soil Index: $20-40$ \\
\hline Leaf application (spring) & F30 & F50 & F70 \\
\hline Soil application (autumn) & H30 & H50 & H70 \\
\hline
\end{tabular}

Monitoring of biological soil-parameters

Twice a year - at the end of March and at the end of October - soil samples are taken from a depth of 0 to $30 \mathrm{~cm}$ and examined for the parameters humus, air-nitrogen fixing bacteria and phosphormobilizing bacteria. Figures 1 to 3 show the dynamics of these three parameters over a 12-year period: 
Air nitrogen-binding bacteria ( $\left.10^{6} \mathrm{CFU} / \mathrm{g}\right)$ over 12 years

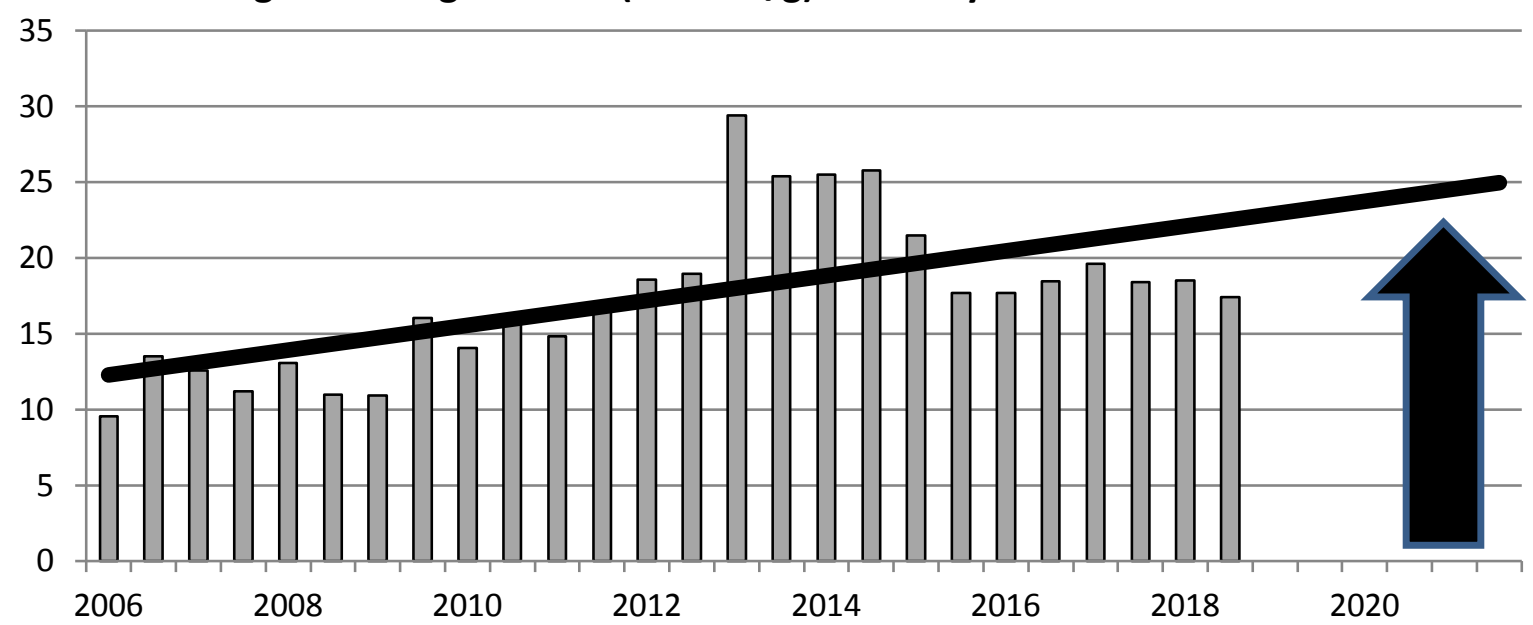

Fig. 1.

Phosphorus mobilizing bacteria $\left(10^{6} \mathrm{CFU} / \mathrm{g}\right)$ over 12 years

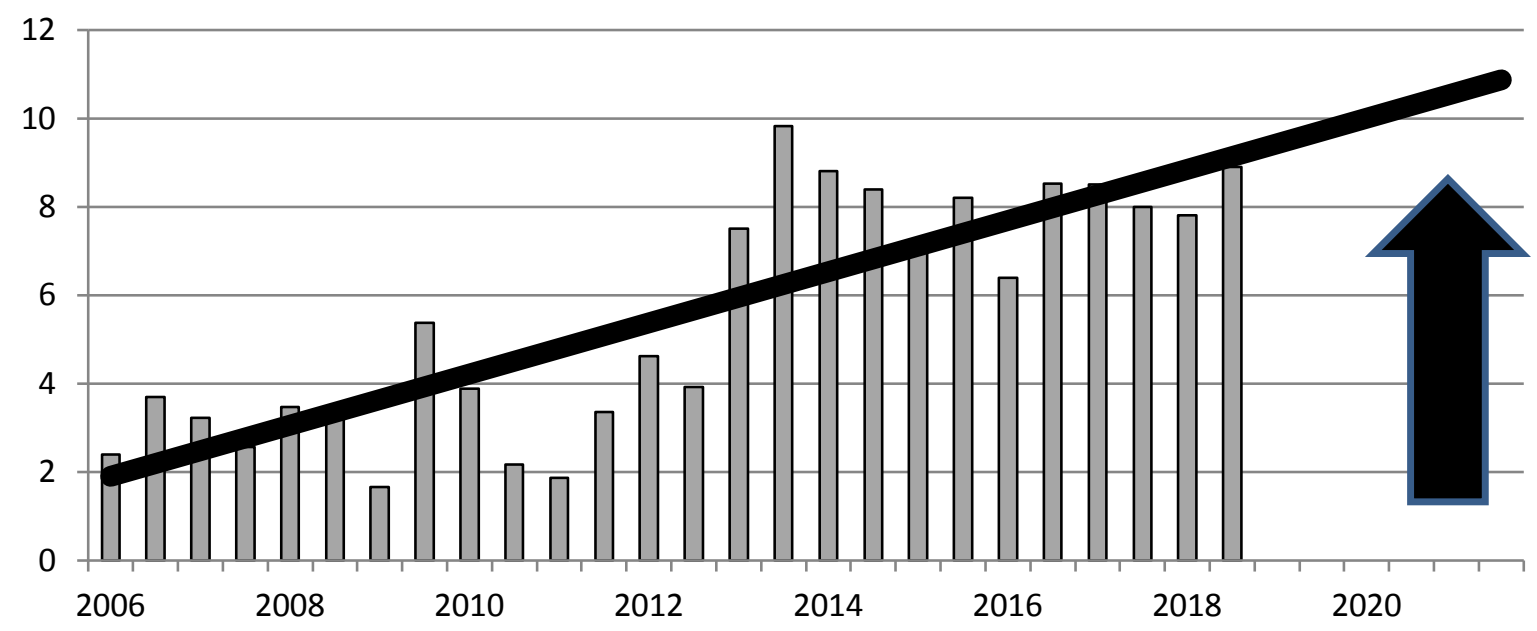

Fig. 2

Humus (\%) over 12 years

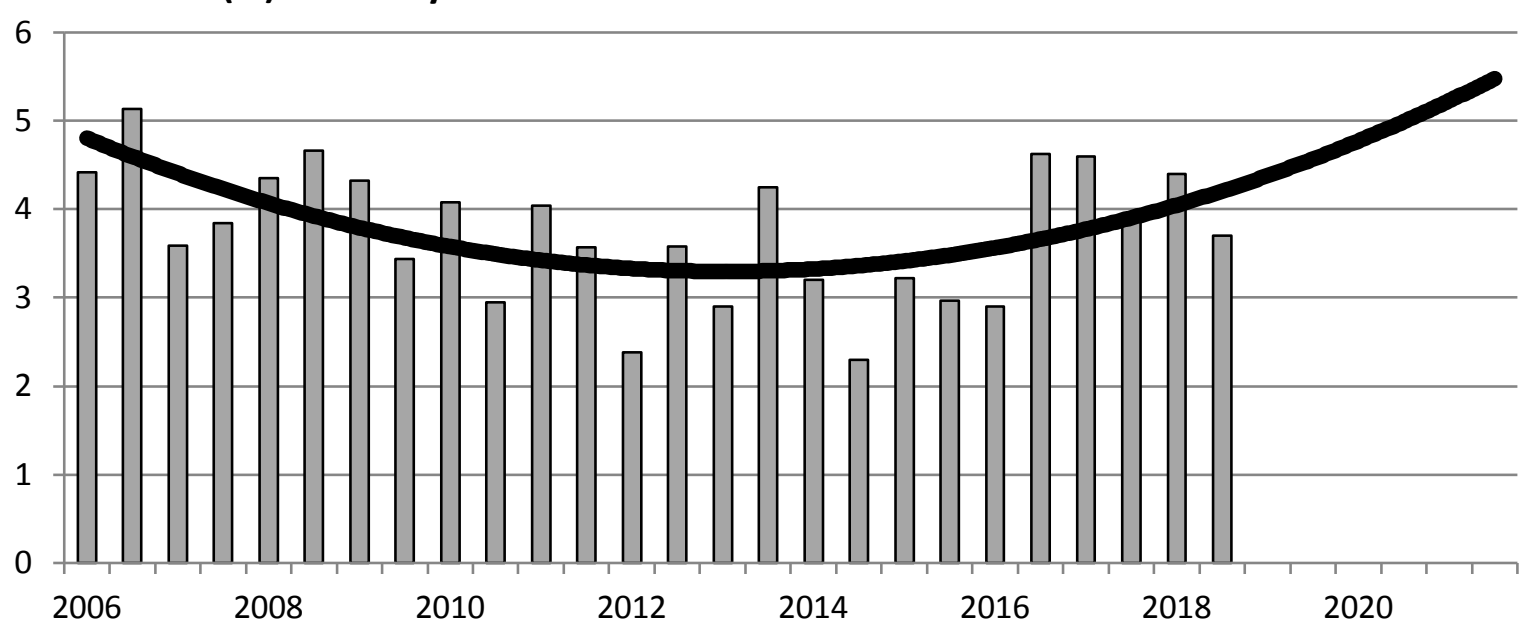

Fig. 3 


\section{Results and discussion}

The particular specific effectiveness of daRostim ${ }^{\circledR}$ TANDEM is based on the combinatorial effect of phytohormones and humic acids (2nd generation PHC tandem technology). According to our findings, it is mainly the phytohormone component in the PHC that makes it possible to obtain the genetic to maximize the yield potential of a variety optimally. Phytohormones control and regulate the growth of plants in all stages of development, e.g. in germination, growth, seed maturity, flower formation or leaf fall. They are the messenger substances that circulate between the plant tissue, transport information and trigger specific reactions. In a complex interaction, they also help the plant to adapt to changing environmental conditions (drought, temperature, soil $\mathrm{pH}$ ) and to form its own antibodies against phytopathogenic microorganisms. Primarily, the applied PHC increase photosynthetic performance by helping to produce more and faster chlorophyll and form larger leaf areas. The total amount of assimilates produced per unit time increases and this "more" is used in a secondary regulatory effect depending on the growth phase, the climatic factors and the metabolic situation in the root area (nutrient availability, water) of the plant for optimal reproduction, so the yield. The soil bacteria also benefit from this assimilate redistribution. The mean concentration of air nitrogen-binding bacteria increased by two times in 12 years on the 170 trial areas from 11 million CFU/g (2006) to 22 million CFU/g (2018), and for phosphor-mobilizing bacteria by six times from 1.5 million $\mathrm{CFU} / \mathrm{g}$ to $9.0 \mathrm{Million} \mathrm{CFU} / \mathrm{g}$. By the additional PHC application in autumn increased the biological soil index BSI *, calculated from the relationship BSI $*=23 / 100 *(\mathrm{~N}+\mathrm{P})+\mathrm{H}[2]$, by $25 \%$ (see Figure 4 and 5).

BSI* (2006-2012)

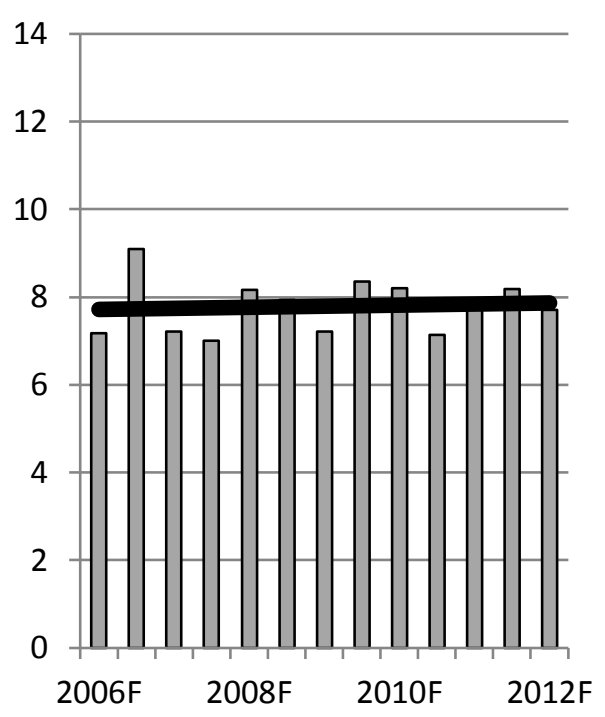

Fig. 4
BSI* (2012-2018)

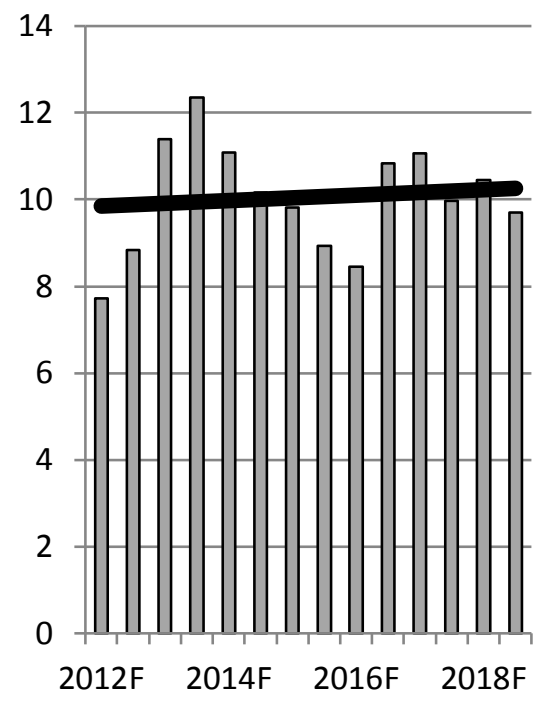

Fig. 5

With the "more" of air nitrogen-binding soil bacteria, the working point of the biological-nitrogen part of yield in the YEN-chart shifts towards higher yields with less nitrogen fertilizer use, the production functions shift in sync. As a result of the additional activation of soil biology by the PHC preparations, under the conditions of intensive cultivation in Germany on the 170 experimental areas an average yield increase of $13.7 \mathrm{CE}$ was already established in 2016 with a simultaneous reduction of nitrogen fertilizer use by $26.2 \mathrm{kgN} /$ ha. However, not all soils benefit equally well. The larger the soil index, the greater the average effect. This suggests that black soil with a soil index of 100, which provides the best natural conditions for the development of soil biology, could be particularly efficiently rehabilitated by PHC 
applications. Practical sector or yield increase and nitrogen fertilizer reduction vs soil index sector show Figure 6 and 7.

yield increase (CE/ha)

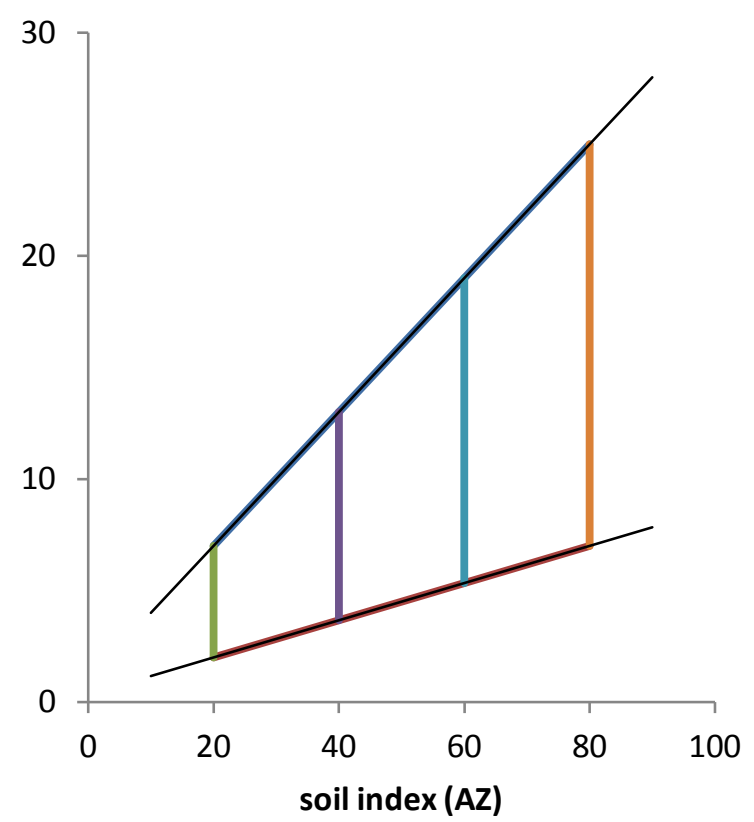

Fig. 6

\section{$\mathrm{N}$-fertilizer reduction $(\mathrm{kgN} / \mathrm{ha})$}

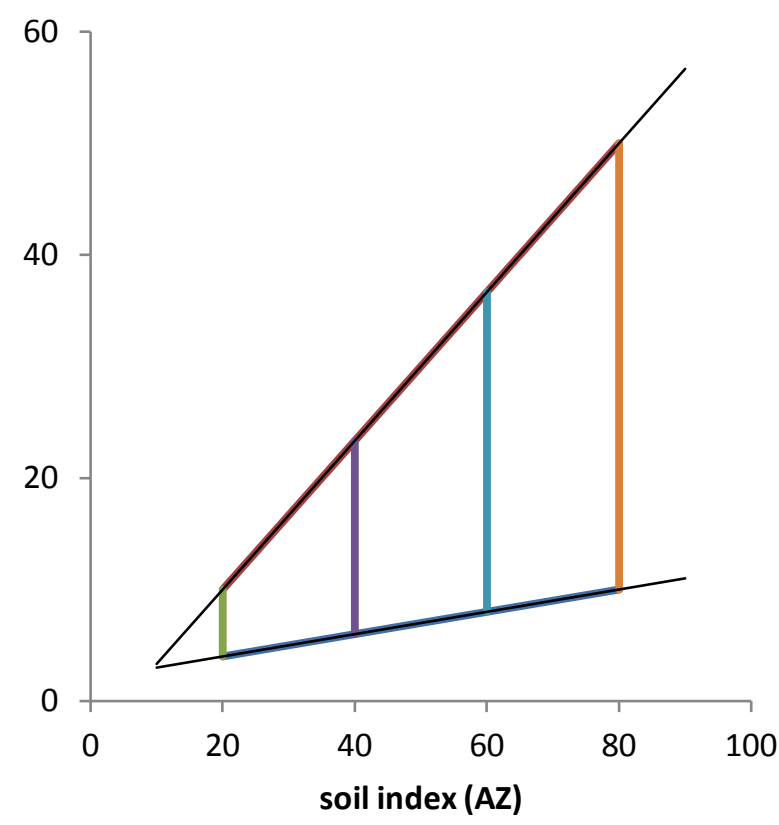

Fig. 7

The monetary effect from fertilizer saving and yield increase is very sustainable: 1 EUR PHC use beats conservatively $(0.6 \mathrm{EUR} / \mathrm{kg} \mathrm{N}, 10 \mathrm{EUR} / \mathrm{CE})$ with 2 to 6 EUR profit. Our results are shown in Table 2.

Table 2. Monetary effect of TANDEM-Application

\begin{tabular}{|l|c|c|c|}
\hline \multirow{2}{*}{ PHC- Effect (EUR/ha) } & \multicolumn{3}{|c|}{ Soil index } \\
\cline { 2 - 4 } & $20-40$ & $40-60$ & $60-80$ \\
\hline Economic yield & 51,30 & 179,90 & 239,70 \\
\hline $\begin{array}{l}\text { Total cost of preparations used in thw applications } \\
(\mathrm{F}+\mathrm{H})\end{array}$ & 21,60 & 31,20 & 41,04 \\
\hline benefit /cost - ratio & $\mathbf{2 , 3 8}$ & $\mathbf{5 , 7 7}$ & $\mathbf{5 , 8 4}$ \\
\hline
\end{tabular}

\section{Expression of thanks}

The author thanks the companies in Bückwitz, Borna, Cavertitz, Doberschütz, Dittmannsdorf, Elsterberg, Gimmel, Großräschen, Görzig, Großthiemig, Hohenroda, Herzogswalde, Lauenhain, Münchenbernsdorf, Pahren, Reichenbach, Sprotta, Uftrungen und Wülknitz for their many years of stable cooperation.

\section{Reference}

[1] W. Nowick - The bioactive PHC - phytohormone - humic acid compositions of the series TANDEM and results of their long-term effect on productivity of plant production in Germany - XIV Conference daRostim2018 Biologically active preparations for plant growing - Belarusian State University, Minsk, 2018, P. 16-19.

[2] W. Nowick, I. Semenjuk, E. Karpenko - Sravnytel'nye yssledovanyja dejstvyja humynovykh preparatov dlja sezonnoj obrabotky pochvy na opytnykh poljah Germanyy v ramkax prohrammy Tandem $^{12 / 21}$ - XII Conference daRostim2018 Biotechnology for agriculture and environmental protection - Odessa I.I.Mechnikov National University, Odessa, 2016, P. 173-177. 